\title{
Dynamic carbonate sedimentation on the Northern Line Islands
}

\section{Ridge, Palmyra Basin}

May 2016 draft

$5 \quad$ Mitchell Lyle (Corresponding Author)

College of Earth Ocean and Atmospheric Sciences, Oregon State University

mlyle@coas.oregonstate.edu

Robert Pockalny

10 Graduate School of Oceanography, University of Rhode Island

rpockalny@uri.edu

Pratigya Polissar

Lamont-Doherty Earth Observatory, Columbia University

15 Polissar@ldeo.columbia.edu

Jean Lynch-Stieglitz

School of Earth and Atmospheric Science, Georgia Institute of Technology

Jean@eas.gatech.edu

20

Samantha Bova

Department of Earth Environmental and Planetary Sciences, Brown University

SamanthaBova@Brown.edu

25 Ann G. Dunlea

Department of Earth and Environment, Boston University

adunlea@bu.edu

Heather Ford

30 Lamont-Doherty Earth Observatory, Columbia University

hford@ldeo.columbia.edu

Jennifer Hertzberg

Department of Oceanography, Texas A\&M University, now at

35 Marine Sciences Program, University of Connecticutt

jennifer.hertzberg@uconn.edu

Steven Hovan

Department of Geoscience, Indiana University of Pennsylvania

40 hovan@iup.edu

Allison Jacobel

Lamont-Doherty Earth Observatory, Columbia University 
\acobel@ldeo.columbia.edu

45

Christina King Wertman

Graduate School of Oceanography, University of Rhode Island

c_king@gso.uri.edu

50 Ashley E. Maloney

University of Washington, School of Oceanography

ashjames@uw.edu

Richard W. Murray

55 Department of Earth and Environment, Boston University

rickm@bu.edu

Julia Shackford Wilson

Department of Oceanography, Texas A\&M University

60 juliakwilson.13@gmail.com

Katherine Wejnert

Fernback Science Center, Atlanta Georgia

katherine_e_wejnert@dekalbschoolsga.org

65

Ruifang C. Xie

Dept of Biogeochemistry, Max Planck Institute for Chemistry, Mainz Germany ruifang.xie@mpic.de

801.0 ABSTRACT:

The Line Islands Ridge (LIR), located south of the Hawaiian Islands between $7^{\circ} \mathrm{N}$ and $1^{\circ} \mathrm{S}$, is one of the few large central Pacific regions shallower than the regional carbonate compensation depth. Thick sequences of carbonate sediments have 
accumulated around the LIR despite it being located in the sediment-starved central

85 tropical Pacific. The LIR is an important source of carbonates to the surrounding region and deposition around the LIR has expanded the equatorial Pacific carbonate sediment tongue by about $5 \%$ of its total area. Furthermore, sediments on the ridge are potentially important paleoceanographic archives. A recent survey at the crest of the LIR finds evidence for high current activity, significant erosion, but overall net

90 sediment deposition. Currents are strong enough to form sediment waves and lee drifts in the Palmyra Basin, at the northern terminus of the LIR. Sediments along the LIR are pelagic foraminiferal sands that are easily eroded and flow out into the surrounding abyssal plain in active submarine channel systems. As channels migrate, pelagic sediments fill in the abandoned channel arms. Despite significant

95 sediment losses from the top of the ridge, $1.3 \mathrm{~km}$ of sediment has accumulated in the upper Palmyra Basin over basement formed 68 to 85 million years ago (Ma). Late Neogene erosion may be more extensive than earlier erosion cycles, in response to reduced sediment production as the Palmyra Basin exited the high productivity equatorial latitudes. Sediments with good stratigraphic order needed for

100 paleoceanographic study are limited in this dynamic sedimentary environment, but can be found with proper survey.

\section{KEYWORDS}

Central Pacific, carbonate sediments, Line Islands Ridge, seismic stratigraphy, 105 carbon cycle 


\subsection{REGIONAL SETTING:}

The Line Islands Ridge (LIR, Figure 1) is one of the few large areas in the central Pacific that stands above the regional carbonate compensation depth of

$110 \sim 4800 \mathrm{~m}$ (Berger et al., 1976). Elevated topography associated with the LIR extends $\sim 1000 \mathrm{~km}$ southeast from $7^{\circ} \mathrm{N}$ to $\sim 1^{\circ} \mathrm{S}$. The highest peaks of the LIR form the Line Island chain, from Kingman Reef to Kiritimati (Christmas) Island (Figure 1). The width of the LIR above the $3000 \mathrm{~m}$ depth contour varies from $\sim 200 \mathrm{~km}$ in the north to $<100 \mathrm{~km}$ at its southern end.

115 Sediments on the LIR should prove to be an important archive to study Pleistocene glacial-interglacial changes in surface ocean conditions (Lynch-Stieglitz et al, 2015) as well as the Cenozoic evolution of the Pacific Ocean and circumpolar deep-water flow in the abyssal Pacific with additional scientific drilling. The high topography of the LIR provides a platform sufficiently shallow for carbonate records

120 to exist on Cretaceous-age crust. The LIR also spans across the central Pacific equatorial region to provide transects needed to study the paleoceanographic evolution of the central Pacific.

Seismic stratigraphy around the LIR can potentially be used to understand changes in deep Pacific flow through changes in regional sediment deposition and

125 formation of hiatus intervals. Circumpolar deep water (CPDW) now flows northward in the western Pacific, and splits to flow around the Hawaiian Islands (Talley, 2007). CPDW flowing east is blocked by the LIR, but CPDW eventually flows around it to the north between the LIR and Hawaii. A branch of bottom water 
returning from the eastern Pacific flows westward along the equator to the south of

130 the LIR (Johnson and Toole, 1993).

\subsection{Origin of LIR basement topography}

Originally the LIR was thought to be a hotspot trace because the ridge extends in the general direction of Pacific Plate motion (Morgan, 1972). However dating of basalts along the chain failed to identify an age progression with distance

135 (Schlanger et al, 1984). Much of the northern Ridge was built during two major periods of late Cretaceous volcanism, 81-86 Ma and 68-73 Ma (Davis et al., 2002) on ocean crust that was formed at about 120 Ma. Davis et al (2002) proposed that LIR volcanism was associated with a broad upwarping of mantle in the South Pacific Superswell region (Larson, 1991, Adam and Bonneville, 2005). A more recent

140 interpretation (Pockalny et al., 2015) suggests the LIR may result from two small overlapping hotspot traces, one associated with the Crough Hotspot and one with a possible hotspot near Pukapuka Ridge.

LIR topography is also different from that of Hawaii, where eruptions have been restricted to relatively few volcanic centers (Figure 1) so that large but

145 separate volcanic edifices are formed. Instead, the LIR is composed of multiple smaller volcanoes, spread over $1-2^{\circ}$ of longitude across the general LIR trend. In the region between $5^{\circ}$ and $7^{\circ} \mathrm{N}$, the LIR bathymetry swells to form the largest region of shallow bathymetry in the chain (Figure 2). The high topography consists of two bounding basaltic ridges to the southwest and northeast with a basin in the center

150 filled with about $1.3 \mathrm{~km}$ of sediment. We refer to the northeastern ridge as 
Schlanger Ridge, the southwestern ridge as Kingman Ridge, and the basin between them as Palmyra Basin.

Kingman Ridge links 3 seamounts with relatively deep saddles between them. Two of the three seamounts also reach the sea surface to form Kingman Reef

155 and Palmyra Atoll. Schlanger Ridge, in contrast, is more massive and connected, but the crest of Schlanger Ridge is about $1000 \mathrm{~m}$ below the sea surface. To the south, Palmyra Basin abuts against another southeast trending basement ridge that we call Langseth Ridge. Langseth Ridge is the southeast terminus of Palmyra basin (Figure 2). The seamount that rises to form Kingman Reef has been dated to $70 \mathrm{Ma}$ by ${ }^{40} \mathrm{Ar}-$

$160{ }^{39} \mathrm{Ar}$ total fusion dating, (Davis et al, 2002), while a basalt from a dredge from Schlanger Ridge was dated at $76 \mathrm{Ma}$, also using the ${ }^{40} \mathrm{Ar}-{ }^{39} \mathrm{Ar}$ total fusion method (Dredge 123D; Schlanger et al, 1984).

\subsection{Sediments surrounding the LIR}

The LIR is apparently a source of sediments to the surrounding sea floor

165 (Figure 3; Divins, 2003; updated in Whittaker et al, 2013). The sediment deposits around the LIR are all much thicker than typical pelagic deposits on Cretaceous seafloor in the Pacific. The sediment apron surrounding the LIR is a major pelagic sediment accumulation within the tropical Pacific comparable to the thickness of sediments at the crest of the eastern equatorial Pacific sediment bulge $(\sim 600 \mathrm{~m}$ at

170 its crest; Hays et al, 1969, van Andel et al, 1975; Mitchell and Lyle, 2005).

Typical sediments to the north of the Clipperton Fracture Zone (FZ) are thin, 150-250 m (van Andel et al, 1975; Lyle and Wilson, 2006; Pälike et al, 2010) because the ocean floor was formed in the early Cenozoic or late Cretaceous when 
the CCD was shallow (Arthur et al., 1985; Pälike et al, 2012). Consequently,

175 carbonates typically were dissolved before burial on the Cretaceous and Paleogene flanks of the mid-ocean ridge, leaving only clays and radiolarian ooze. Sediments to the south of the Clipperton FZ are thick in the position of the early Miocene equator in the eastern Pacific (van Andel et al, 1975) but thin to the west. The region surrounding the LIR south of Clipperton FZ (which now cuts across the LIR at about

$1802^{\circ} \mathrm{N}$ ) were south of $4^{\circ} \mathrm{S}$, i.e. in a low sedimentation regime, during the major high sedimentation interval of the Oligocene and early Miocene. Consequently there is a relatively thin sediment pile when compared to sediments to the east in the equatorial Pacific sediment bulge. The eastern Pacific plate trajectory brought sediments in the equatorial bulge through the equatorial high productivity region 185 when sediment production was highest, during the Oligocene and early Miocene. Three DSDP sites have been drilled in the vicinity of the LIR that show how sediments were deposited near the LIR. Site 165 is to the northwest (DSDP Leg 17 Shipboard scientific party, 1973, 490 m sediment), Site 315 is to the east (DSDP Leg 33 Shipboard scientific party, 1976, 996 m sediment), and to the south is Site 316

190 (DSDP Leg 33 Shipboard scientific party, 1976; 837 m sediment). Additional sediment thickness data come from analog seismic reflection records acquired in the 1970's (e.g., Normark and Spiess, 1976; Orwig, 1981) and from those by the Glomar Challenger during the DSDP drilling expeditions themselves (Raff, 1973; Schlanger and Winterer, 1976). Apparently, neither the thickness of sediment found 195 at Site 316 nor in nearby seismic profiles (Schlanger and Winterer, 1976) was honored in the Divens/Whittaker grid shown in Figure 3. A ramp of thick sediments 
is found from the base of the LIR to the position of Site 316, averaging a thickness around 1 sec of two-way travel time (TWTT) or around $800 \mathrm{~m}$.

The regional sediment thickness map in Figure 3 depicts the LIR crest as 200 essentially sediment free, reflecting the lack of older seismic reflection and drilling data there. However, a Gloria side scan sonar survey in 1991, which also gathered seismic reflection data, found thick sediments within Palmyra Basin at the northwest end of the LIR (Paskevich et al, 2011; Barth et al, 2013, Figure 2).

Shallow water carbonates form only a small part of the excess sediment

205 around the LIR. They were only found in the late Cretaceous basal volcaniclastic sediments of Sites 165 and 316, and from the middle Cretaceous at Site 315 (Jackson and Schlanger, 1976; Schlanger et al, 1984). The rest of the sediments are pelagic. Pelagic carbonate turbidites flowing from the LIR to the surrounding apron were critical to build the thick sediment column at Site 315 (DSDP Leg 33 Shipboard

210 Scientific Party, 1976). Orwig (1981) has also traced turbidites sourced from the LIR that traveled to the northwest from Palmyra Basin toward Site 165, as well as to the southwest of the LIR. Because Site 165 is now well below the Neogene CCD (5040 m vs $4700 \mathrm{~m}$ CCD) there has been little sediment deposition since the early Miocene. Significant amounts of sediment have been generated on the LIR but then shed to 215 the surrounding sea floor. Cretaceous turbidites sourced just after the LIR formed carried both volcaniclastics and the shallow water carbonates from the LIR.

Sediment sequences around the LIR are rarely complete but instead have significant time gaps. Hiatus periods are not regionally consistent however (Jackson and Schlanger, 1976), but apparently reflect the strength and temporal variability of 
220 abyssal current flow around the LIR. Site 165 is missing Neogene sediments, for example, while Site 315 is missing part of the lower Miocene. The southern drillsite, Site 316, is missing much of the Oligocene. Neogene sediment sections are highly variable in thickness around the LIR, based on interpretations of seismic reflection profiles in the vicinity of the LIR (Raff, 1973, Schlanger and Winterer, 1976). In this paper, we examine sediment deposition in the Palmyra Basin, a shallow north-facing basin at around $7^{\circ} \mathrm{N}$ on the LIR (Figure 2). Despite the large losses of sediment from LIR to the surrounding terrain there has been net sediment accumulation within Palmyra Basin, with average sedimentation rates since $75 \mathrm{Ma}$ similar to Pleistocene sedimentation rates in the region. Assuming 75 Ma crust, the

230 average sedimentation rate over the Palmyra Basin center is $1.7 \mathrm{~cm} / \mathrm{kyr}$ compared to sedimentation rates for MIS 1-3 of 1.5 to $1.7 \mathrm{~cm} / \mathrm{kyr}$ for cores nearby (cores 34, 35, and 37BB; Lynch-Stieglitz et al, 2015). Seismic horizons within Palmyra Basin are neither clean nor continuous. Instead, individual horizons can be traced for relatively short distances even though these horizons make up discernible sediment

235 packets. The discontinuous seismic horizons are a result of downslope transport and a high-energy current regime.

\section{THE MGL1208 LINE ISLANDS RIDGE SURVEY:}

The MGL1208 coring, multibeam sonar, and seismic reflection survey of the LIR was the first major coring expedition to the Line Islands region in the last 30

240 years. Cores were collected along the LIR in order to study the Pleistocene paleoceanography of the central Pacific, including studying glacial-interglacial changes of the intertropical convergence zone (ITCZ), equatorial primary 
productivity, and the El Niño-Southern Oscillation (Lynch-Stieglitz et al, 2015).

Multibeam bathymetry using the Kongsberg EM122 swath mapping system was

245 collected along the entire ship track. Multichannel high-resolution seismic reflection profiles discussed in this paper were collected near $6^{\circ} \mathrm{N}$ (MGL1208 Survey area E) and also south of Kiritimati (Figure 1). Digital $3.5 \mathrm{kHz}$ chirp subbottom profiler data were collected over the complete survey area.

Most of MGL1208 was devoted to locating coring sites and recovering a new

250 set of sediment cores. More than 20 new piston cores, 'Big Bertha' gravity cores ( $6 \mathrm{~m}$ gravity cores using a piston core weight stand), and $2 \mathrm{~m}$ gravity cores were collected along the LIR, with promising coring sites located by multibeam surveys and digital chirp data. The cores are described in Lynch-Stieglitz et al (2015). PleistoceneHolocene sediments in the 2000-3500 m depth range cored on MGL1208 are all

255 pelagic foraminiferal sands and silts with no shallow water components (LynchStieglitz et al, 2015). Typical sedimentation rates range from $\sim 1 \mathrm{~cm} / \mathrm{kyr}$ in the north to $3 \mathrm{~cm} / \mathrm{kyr}$ near the equator.

The data in this paper are from the Palmyra Basin and ridges surrounding it, between 5 and $7^{\circ} \mathrm{N}$ near Palmyra Island (Figures 1 and 2). Palmyra Basin extends

$260 \sim 100 \mathrm{~km}$ in a SE-NW direction, from about $5^{\circ} 40^{\prime} \mathrm{N}$ to about $6^{\circ} 45^{\prime} \mathrm{N}$, Seismic line 1 (Figure 2, Figure 4) was shot near the southeastern crest of Palmyra basin, where the sea floor depth ranges between 2000 and 2400 m below sea level. Seismic line 2 (Figure 2, Figure 5) crosses the foot of the northern seamount on Langseth Ridge, roughly from west to east. 


\section{4. METHODS}

Seismic reflection data for the Line Islands were collected on the R/V Langseth using the onboard Syntrak 960-24 MCS digital data acquisition system with a Digishot source controller (http://www.ldeo.columbia.edu/research/officeof-marine-operations/langseth/scientific-instrumentation). The seismic source for

270 the high-resolution multichannel seismic profiles was two 45 cubic inch (c.i.) generator-105 c.i. injector GI air guns. The seismic reflection data were collected with a $900 \mathrm{~m}, 60$-channel streamer having $12.5 \mathrm{~m}$ group spacing. Shots were spaced at $25 \mathrm{~m}$ and data were recorded for 8 seconds and digitized at $0.5 \mathrm{~ms}$ intervals.

The 60-channel data were stacked after NMO correction and noise reduced

275 via spectral shaping, with a $30 \mathrm{~Hz}$ lower cutoff, $100 \%$ pass from $60 \mathrm{~Hz}$ to $450 \mathrm{~Hz}$ and then ramping down to a high cutoff at $900 \mathrm{~Hz}$. The data were then migrated assuming $1500 \mathrm{~m} / \mathrm{s}$ acoustic velocity. Three seismic reflection lines (19 hours of survey) were collected in the vicinity of Palmyra Basin, and another 33 hours were collected where LIR crossed the equator. Seismic data are archived at the University

280 of Texas Academic Seismic portal of the Marine Geoscience Data System (http://www.ig.utexas.edu/sdc/cruise.php?cruiseIn=mgl1208).

Estimates of depth in the seismic profiles use a seismic velocity of 1500 to $1600 \mathrm{~m} / \mathrm{s}$ in unconsolidated sediments (Hamilton et al, 1982). Total thickness of sediments in Palmyra basin were estimated by comparison to TWTT to basement at

285 Site 315 versus depth drilled, plus shipboard measurements of seismic velocity in the lower sediments to extrapolate below the bottom depth of Site $315 \mathrm{~km}$ (Site 315, DSDP Leg 33 scientific party, 1976). 
Swathmap bathymetry was collected using the Kongsberg EM122 multibeam system on the R/V Langseth. The data were ping-edited to remove outliers using

290 MB-System software (available from http://www.ldeo.columbia.edu/res/pi/MBSystem/) and plotted with the open-source GMT mapping software (http://gmt.soest.hawaii.edu/). Additional swathmap bathymetry data come from the US interagency Extended Continental Shelf Program (ECS; Barth et al, 2013; Gardner and Calder, 2010). The ECS Program data are found along the SW side of

295 Palmyra Basin along Kingman Ridge and to the west of the LIR.

\section{SURFACE FEATURES: EROSION AND CURRENT ACTIVITY}

The most prominent sedimentary features around the crest of the LIR indicate an energetic sedimentary environment with significant sediment movement. Submarine channels are prominent along the edges of LIR, e.g., as found

300 around the rim of Palmyra Basin (Figure 2; Barth et al, 2013), while sediment waves are prominent at the saddle between Kingman and Langseth Ridges (Figures 4,6, 7).

In most of Figure 2, the apparently smooth topography is an artifact of satellite ocean bathymetry (Smith and Sandwell, 1997). Satellite topography is adequate to find large-scale bathymetric features, but cannot resolve bathymetric

305 features $<10 \mathrm{~km}$ in spacing, even as large as abyssal hill topography (Goff et al, 2004). Multibeam mapping is needed to reach bathymetric resolution sufficient to study the sedimentation and its relationship to the LIR seamounts and ridges, as around the rim of Palmyra basin (Figure 2).

The sediments on the LIR are being channeled to the surrounding fan

310 systems via a network of anastomosing small channels that join main channels 
within each sub-basin. They drain to abyssal plains that form the apron surrounding the LIR. A well-imaged large channel system can be seen on Figure 2 at $5.8^{\circ} \mathrm{N}$, $161.5^{\circ} \mathrm{W}$, just south of Palmyra Atoll. A large channel system has been poorly imaged by bathymetry but runs almost due south to north from the upper to the

315 lower Palmyra Basin and carries sediments to the abyssal plain around $6^{\circ} 40^{\prime} \mathrm{N}$, $162^{\circ} 30^{\prime} \mathrm{W}$. The channel system has been better imaged by the sidescan GLORIA survey of the US EEZ around Kingman Reef and Palmyra Island in 1991 (Paskevich et al, 2011, Barth et al, 2013, Jones et al, 2013).

Channels and sub-channels have little sinuosity because they are (1) formed

320 on steep topography, (2) LIR sediments are coarse-grained, and (3) the sediments have little cohesion (Clark et al, 1992). Sediments collected by coring on MGL1208 are typically foraminiferal sands, with about $50 \%$ sand fraction $(>64 \mu$; LynchStieglitz et al, 2015). The remainder is nannofossil carbonate.

The 3 cores attempted in the upper Palmyra Basin in 1800-2100 m of water

325 collected only traces of foraminiferal sand in the core catchers either because the cores did not penetrate deeply enough to retain the sediments or the sediments drained out. The carbonates at the top of the basin are apparently winnowed, much richer in coarse fraction, and are thus too sandy and poorly cohesive to be cored with the methods we used. Sediments with similar composition on the sides of the 330 basaltic seamounts and ridges appear to slough into channels easily, often leaving avalanche scars behind.

The upper Palmyra Basin, where the seismic reflection profiles were acquired (Figure 2, Figure 4, MGL1208 Seismic line 1; Figure 5: Seismic Line 2) is 
divided into a NE channeled regime along the base of Schlanger Ridge and a SW

335 regime with smoother sediments. The NE channels drain from higher topography and are perched with respect to the SW part of the seismic line, where smoother sediments and the basin depocenter are located. A seamount to the south of the main axis of Schlanger Ridge (Figure 2) helps to enclose the NE subbasin and steepen the basement topography. In contrast, the slope above the SW end of

340 Seismic Line 1 is relatively shallow.

Smooth sediments as well as sediment waves are also found in the gap between Kingman and Langseth Ridges (Figures 6 and 7). The smoother sediment fill extends about halfway across the upper Palmyra Basin, from the southern edge to the basin depocenter. Further downslope to the NW, the upper reaches of large

345 channels that drain northward disrupt smooth sediment deposition. These channels are large enough that they can be traced even in the low-resolution satellite bathymetry in Figure 2. To the NE, as Seismic Line 1 passes across the crest of a saddle across Schlanger Ridge, smooth sediments are also deposited. A lee drift of sediments is found to the NE of a small basalt cone in the gap (Figure 4),

350 indicating recent current flow primarily from south to north.

Sediment waves are found at the gap between Kingman and Langseth Ridges (Figure 2, Figure 6). They form north of a step upward in sea floor level possibly buttressed by basement topography (Figure 7). Bottom currents through KingmanLangseth Gap cause a series of sand waves that have $\sim 1.3 \mathrm{~km}$ wavelength and wave 355 heights of 10-20 m (Figure 6). 
The sediment waves have developed over long periods of time, since similar waves can be found to depths of $\sim 0.2$ seconds two way travel time (TWTT), $\sim 150$ $160 \mathrm{~m}$ deep in the sediment column as inferred by the undulating sediment horizons (Figure 7; the right hand side of Seismic Line 1). The wavelength in Figure

$360 \quad 7$ is $\sim 2 \mathrm{~km}$ rather than $1.3 \mathrm{~km}$ because the seismic line cuts the wave field obliquely. Given typical Pleistocene LIR sedimentation rates of $1-2 \mathrm{~cm} / \mathrm{kyr}$ north of $5^{\circ} \mathrm{N}$ (Lynch-Stieglitz et al, 2015), sediment waves have been forming since $\sim 8-16 \mathrm{Ma}$ Large abyssal sediment waves are thought to occur primarily in fine-grained muds at current speeds of 0.05 to $0.25 \mathrm{~m} / \mathrm{s}$ (Flood, 1988; Stow et al, 2009). The

365 foraminiferal sand waves we document here are apparently too coarse for these types of sediment waves-sand waves typically require higher near-bottom current flows of $\geq 0.5 \mathrm{~m} / \mathrm{s}$, and significant sediment supply (Stow et al, 2009). However, hollow whole foraminiferal tests are significantly less dense than a solid calcite or quartz sphere of the same size. Because their effective density is $\sim 1.5 \mathrm{~g} / \mathrm{cm}^{3} \mathrm{vs} 2.7$

$370 \mathrm{~g} / \mathrm{cm}^{3}$ for a solid calcite sphere, they can be eroded very easily (Miller and Komar, 1977). Current speeds in the range of $0.15-0.2 \mathrm{~m} / \mathrm{s}$ are sufficient to erode 100 to $300 \mu \square$ size tests from foraminiferal sands. Moderate currents will also preferentially transport whole tests and leave behind test fragments because the fragments are smaller and denser (Miller and Komar, 1977). Moderate speed

375 bottom currents sweeping through the gap between Langseth and Kingman Ridges into Palmyra Basin could preferentially sort whole tests and deposit them in sediment waves found in Figure 6. We did not core the seamount gap to be able to study the differences in sediment composition there, however. 
Abyssal current velocities over the LIR can be gleaned from the HYCOM data 380 assimilation ocean circulation model reanalysis (Hybrid Coordinate Ocean Model; http://hycom.org) which has a $1 / 12^{\circ}(9 \mathrm{~km})$ horizontal scale and a variable vertical scale. Below $2 \mathrm{~km}$, model ocean layers are $500 \mathrm{~m}$ thick. For the 6-year period from 18 Sept 2008 to 11 Sept 2014, daily average u and v velocity data from every 2nd day were extracted from the HYCOM reanalysis and then averaged to make the

385 current velocities shown in Figure 6. HYCOM model current speeds are high in the vicinity of the Palmyra Basin sediment waves, averaging between $0.2-0.25 \mathrm{~m} / \mathrm{s}$, sufficiently vigorous to form the observed waves (Figure 6).

The HYCOM model may also bias bottom current velocities low. Comparison of HYCOM model eddy kinetic energy to measurements at a moored array in the Gulf 390 of Mexico suggested that HYCOM may underestimate abyssal current velocities by $\sim 40 \%$ (Rosburg et al, 2012). Also, the HYCOM model does not resolve tidal currents, so actual near-bottom velocities may be even larger when the tidal cycle reinforces the mean current. Finally, current speeds should be locally higher at flow constrictions like that formed by the gap between Kingman and Schlanger Ridges 395 than the average in a typical $9 \mathrm{~km} \times 9 \mathrm{~km}$ HYCOM box.

The sediments to the south of the gap are smooth and the topography is significantly deeper than upstream, forming a smooth platform at $\sim 2340 \mathrm{~m}$ water depth, with a step up to the $2250 \mathrm{~m}$ water depth of the Palmyra basin fill. The gap has been adequately surveyed by multibeam to confirm that the platform does not 400 have sediment channels typically found elsewhere near the LIR crest. Such 
smoothing suggests transport by the currents flowing through the gap to fill in channels and smooth the sediment surface.

Sediments only about $250 \mathrm{~m}$ thick are imaged at the SW end of Seismic Line 1 (Figure 7) versus $\sim 1.3 \mathrm{~km}$ of sediment at the depocenter (see Section 6.3 for

405 thickness estimate). However, Seismic Line 1 ends near the base of a seamount rather than in the gap between Kingman Ridge and Langseth Ridge. Within the gap there is about $400 \mathrm{~m}$ of sediment ( $0.5 \mathrm{~s}$ TWTT), as found at the western end of Seismic Line 2 (Figure 5). The thick sediments and smooth topography within the Kingman gap indicates net deposition and the current indicators suggest net 410 transport from the south.

The currents that produce the sand waves have varied through time. Occasional hiatuses can be found at the end of Line 1 (Figure 7) where a surface was formed and there was apparently little sediment deposition for some time. A prominent seismic horizon within the sand waves is marked on Figure 7 roughly at

$415150 \mathrm{~ms}$ TWTT ( $120 \mathrm{mbsf})$ and marks the upper surface of a series of sediment waves. The lower surface of this sediment packet has cut into previously deposited sediments and is found at a depth about $75 \mathrm{~m}$ below the hiatus surface. These sediments mark a relict surface from an interval of higher current speeds through the gap.

\section{6. SEISMIC HORIZONS AND PALMYRA BASIN CHANNELS}

Although basaltic basement forms the high topography both to the north and south of Palmyra basin, the high topography between the two basement ridges results from sediment fill (Figures 4, 5, 8). Despite surface erosion, there has been 
net sediment deposition since the late Cretaceous, with more than $1 \mathrm{~km}$ of sediment

425 deposited in the axis of the central basin. Even with strong currents, the gaps in both Kingman and Schlanger Ridges are sediment covered. Within the saddle on Schlanger Ridge at the NE end of Line $1\left(6^{\circ} 20^{\prime} \mathrm{N}\right.$; Figure 4) flat topography formed by sediments has gradually expanded southward into the basin, perhaps by relatively high supply of sediments from the rest of Schlanger Ridge and by tidal 430 currents moving sediment to the ridge flanks.

Figure 4 is a comparison between the surface bathymetric features from the multibeam survey with the seismic reflection profile along Seismic Line 1. Major channel systems are found on both sides of Schlanger Ridge; the northern channel is outside of Palmyra Basin and drains to the east, while the channel within Palmyra

435 Basin flows to the southwest and is perched relative to the rest of Palmyra Basin. Both channels are cutting down into older sediments. Significant sediment erosion ( $\sim 500 \mathrm{~m})$ has occurred on either side of Schlanger Ridge within the channels, but 200-600 m of older sediments still remain (Figure 4, Figure 8). The interchannel highs do not have interpretable seismic stratigraphy. The poor seismic continuity

440 within the channels may result from repeated episodes of filling followed by channel cutting.

A second system of small wide channels occupies the upper Palmyra basin to the south of the sedimentary ridge that divides the central channel system from the more deeply cut channels in the NE (Figure 4). There is net sediment deposition 445 near the basin axis-older deeper channels are buried under younger sediment fill. Unlike the channels near Schlanger Ridge that originate on basalt seamounts and 
relatively steep topography, there is a gentle slope upwards to the crest of Palmyra Basin $20 \mathrm{~km}$ to the east and $100 \mathrm{~m}$ shallower in depth than the SW end of Seismic line 1 (Figure 2). The lower net slopes leads to less erosion.

Line 1, as shown by truncation of sediment layers, near the lowest point of Line 1. Further southwest, the sediment waves discussed in the last section are slowly burying high basement topography near Kingman Ridge.

This broad channel near the center of Seismic Line 1 flows westward within

455 the Palmyra Basin to eventually join with a large channel flowing northward away from Kingman Ridge (Figure 2) and the combined system then flows north and downslope out of the Palmyra Basin. The channels carry sediment from the ridges down the length of Palmyra Basin and as far north as DSDP Site 165 (Orwig, 1981), at least through the early Miocene. Further survey and analysis is needed to make a

460 quantitative estimate of sediment loss from Palmyra Basin to the north, however.

\subsection{Continuity of LIR Seismic Horizons: comparison to Cocos Ridge}

There is poor continuity along seismic horizons from the LIR (Figure 9, top). Sediment layering on the LIR contrasts with the classic pelagic drape found on the north flank of the Cocos ridge in the eastern equatorial Pacific (Figure 9, bottom;

465 Line 2 from the MV1014 Cocos Ridge survey, Liao and Lyle, 2014). Both seismic lines are played back to the same scale, and both were shot with paired 45-105 cubic inch GI guns. Seismic horizons found in the Cocos Ridge profile are easy to trace along the entire line despite significant changes in topography, sediment 
thickness, and occasional erosion. Erosional areas on the Cocos Ridge are easy to 470 identify by breaks in seismic horizon continuity.

In contrast, the seismic horizons in the Palmyra Basin are not nearly as continuous. Seismic horizons are prominent for a few $\mathrm{km}$, and then often fade away. Reflection amplitudes often abruptly change strength, as at the boundaries of channels. The changes in amplitude make the seismic record appear blotchy. We

475 hypothesize that the poor continuity is due to the dynamic nature of sedimentation in the Palmyra Basin and that changes in seismic amplitude reflect along-strike changes in sediment physical properties (grain size, porosity, bulk density) caused by current sorting and the resulting variability in local deposition environments. Sediments may not only be sorted before being deposited by the high currents, but 480 they can also be reworked as currents or density flows move them from their place of initial deposition to where they are finally buried.

The difference in seismic response of sediments on Cocos Ridge with respect to those in the Palmyra Basin results from multiple factors: (1) higher biogenic silica content of the biogenic carbonates on Cocos Ridge, (2) lower current speeds, 485 and (3) lower gradient from the sediment sources to the depocenter. Cocos Ridge sediments are biogenic carbonates but also have 10-60\% diatom bio-silica (ODP Leg 202 Scientific Party, 2003). In contrast, LIR sediments are essentially $100 \%$ carbonate. Cyclic deposition of carbonate-rich versus carbonate-poor sediments produces and the strong density contrast between these two sediment types 490 produces good acoustic impedance changes between layers and strong, easily traceable seismic horizons typical of the Cocos Ridge and the eastern Pacific in 
general (Liao and Lyle, 2014, Mayer et al., 1986). The diatoms also form a sediment framework to help bind together the carbonates and keep them from eroding as easily as pure carbonates.

Both mean and maximum current speeds are lower at Cocos Ridge as compared to the LIR and concentrated around the ridge tops (Figure 10, as compared to Figure 6; note the different color schemes). Maximum near-bottom current speeds at the LIR are $0.2-0.25 \mathrm{~m} / \mathrm{s}$, with spots that exceed $0.4 \mathrm{~m} / \mathrm{s}$. Current speeds are in the range of 0.15 to $0.20 \mathrm{~m} / \mathrm{s}$ along the Cocos Ridge crest. These are

500 sufficient to winnow sediment and preferentially erode fines from the top of the ridge (Marcantonio et al, 2014; Liao and Lyle, 2014) but weaker maximum velocities $(\sim 0.1 \mathrm{~m} / \mathrm{s})$ downslope allow relatively even pelagic sedimentation of the resuspended sediment near the Cocos Ridge depocenter (near Site 1241).

Finally, the gradient from the top of Cocos Ridge to the depocenter is

505 relatively shallow so that channeling is not as favored. The Cocos Ridge drops only $300 \mathrm{~m}$ over $50 \mathrm{~km}$ from the top of the ridge to Site 1241 , so that there is less gradient to allow development of channeling. The Cocos Ridge, at least near Site 1241, appears to be a system where the downhill sediment flux is dominated by resuspension and downhill transport, while the LIR sediments are redeposited via 510 channeled flows.

\subsection{Modern sediment deposition and channeling from seamounts at the LIR}

Paradoxically, where LIR sediments are not disturbed or moved, sediment packets can be correlated over long distances. Pleistocene cores were recovered on 
MGL1208 spanning $800 \mathrm{~km}$ along the LIR that all have a common bulk density

515 stratigraphy also replicated by oxygen isotope stratigraphy (Lynch-Stieglitz et al, 2015). However, in order to collect undisturbed Pleistocene sediment sections, the MGL1208 scientific party had to search for small areas of flat topography where sediments had not sloughed off LIR slopes. These areas were typically found on interfluves between active channel systems and at water depths $\sim 3,000 \mathrm{~m}$. Careful

520 surveying was essential for finding suitable areas to core.

The high energy at the sea floor along the LIR and easy erodibility of the sediment can also result in significant local hiatuses and sediment redeposition at any particular location. Within the MGL1208 core set, some cores had stratigraphically complete sections for up to $450,000 \mathrm{kyr}$, but others recovered only

525 a few meters of undisturbed sediments before a hiatus was reached.

Seismic Line 2 (Figure 5; see Figure 4 for line location) follows along the base of the Langseth Ridge and gives insights into how sediment forms channels as they drain sediments from basement high topography. The beginning (western end) of Line 2 is at the gap between Kingman and Langseth Ridges where there is smooth

530 topography and thick sediments. There is also a strong reflection shallow in the section that may be the same hiatus noted in Figure 7. The seismic horizons have little continuity, like Seismic line 1, also showing the dynamic depositional environment.

As Seismic Line 2 crosses over the toe of the seamount to the south of the gap

535 (Figures 2 and 4), deposition of sediment in between minor basement ridges is imaged. Oldest sediments were preferentially deposited in basement valleys 
between spurs from the seamount with some sediment drape. Channels originating from Langseth Ridge now cut into the youngest sediment column (Figure 5) where much of the sediment surface may be relict. Surprisingly, the channels are only

540 partly contained by the basalt ridges. Many basalt spurs were first buried by sediments and then have been exhumed later. The largest channels have developed on the eastern end of Seismic Line 2, as the slope starts to fall away to the southeast, into the next basin south of Palmyra Basin along the LIR. It is clear from the multibeam bathymetry that the channels originate on Langseth Ridge, and likely

545 result from focused downflow of foraminiferal sands. However, the ubiquity of channels points to a high production and deposition of sediments on the LIR basalt ridges, that feed significant volumes of sediment into the basins via the channel systems.

\subsection{Sediment Deposition in Palmyra Basin}

Figure 8 is an interpretation of Seismic Line 1. Basalt basement in the center of Palmyra Basin is now at a depth of about $3500 \mathrm{mbsl}$, or $\sim 2 \mathrm{~km}$ below the flanking ridge heights, and $\sim 2 \mathrm{~km}$ above the average sea floor surrounding the LIR. Even if the ridges were near sea level when they first formed, Palmyra Basin was still relatively deep although uplifted from typical sea floor..

555 There is no ground truth for a seismic stratigraphy of the basin, but it is likely that the lower (brown) unit is primarily Cretaceous and early Paleogene in age, given that the LIR formed around 70-85 Ma. At Site 315, the Paleocene and Eocene are marked by low sedimentation rates (DSDP Leg 33 Scientific Party, 1976), so we 
assume that there is only a thin Paleogene section. We have picked basement as the

560 hard lower reflections. However, this may also include some cherty sections near basement difficult to distinguish from basalt. Cherts have been found in the Paleocene-Oligocene sections of Sites 315 and 316.

Also based on Site 315, we propose that most of the deposition in the basin occurred in the late Oligocene-early Miocene, when Palmyra Basin was carried

565 across the equatorial zone by plate tectonics ( $\sim 18$ Ma equator crossing using a fixed hotspot model, Engebretson et al., 1985 with Gripp and Gordon, 1990 for 0-5 Ma). A similar age of equator crossing (18 Ma) is achieved using the hybrid Torsvik et al (2008) paleomagnetic absolute reference frame plate model.

Assuming that the brown unit in Figure 8 is probably late Cretaceous-

570 Paleogene, we propose that the blue unit is Oligocene-middle Miocene, and the light green sediment unit is possibly middle-late Miocene. Based on typical sedimentation rates, the youngest pink unit is probably $<5$ Ma and represents the Plio-Pleistocene.

Thick sediments are found in the center of Palmyra Basin, with a total TWTT 575 of $1.4 \mathrm{~s}$. If acoustic velocities within Palmyra Basin sediments are similar to those at Site 315, there is $1.3-1.4 \mathrm{~km}$ of sediment at the deepest point. From the Site 315 seismic-drilling comparison, $1.1 \mathrm{~s}$ TWTT is equivalent to $1 \mathrm{~km}$ of sediment over basement (Site 315, DSDP Leg 33 scientific party, 1976), and using an estimated sediment velocity of $2.3 \mathrm{~km} / \mathrm{s}$ in the lower Site 315 sediments, the addition 0.3

580 seconds should be equivalent to about 350 additional meters of sediment. 
While there is no seismic cross-line from MGL1208 down the axis of Palmyra Basin, it is clear from the bathymetry and confirmed by the GLORIA seismic reflection data reported by Barth et al (2013) that the entire Palmyra Basin is a thick sediment pile. The northern LIR topography thus combines basaltic volcanism

585 that created the topographic framework surrounding Palmyra Basin, and sedimentation that has since filled it. The LIR edifice ends at about $7.5^{\circ} \mathrm{N}$ where the volcanic topography that makes up Kingman and Schlanger Ridges ends and where there is a gap to the next major seamounts to the north. Excess sediment flows out in channels extending to the north of the LIR.

Initial sediment deposition in the Cretaceous was biased towards the NE (Schlanger Ridge) side of Palmyra Basin (Figure 8). Significant deposition occurred in the NE end of Line 1 during the brown time interval, with less deposition to the southwest. The upper boundary of the brown unit appears to be truncated at both ends of the seismic line, in the NE and SW. Because Seismic Line 1 crosses a

595 subbasin near Schlanger Ridge with seamounts surrounding it on 3 sides, sediment deposition in the NE was enhanced by downslope sediment transport from the Schlanger Ridge.

As the basin matured, the axis of sedimentation migrated to the southwest and sediments began building up at the southwest end of the profile. Little sediment 600 was deposited at the SW end of Seismic Line 1 during the brown interval. In contrast, the blue sediment unit (Oligocene-lower Miocene?) is thickest in the center of the basin. The upper boundary appears conformable with the overlying 
sediments. Both the brown and blue units thin significantly as Kingman Ridge is approached, in the SW part of Figure 8.

605 We could not trace the light green unit into the channeled subbasin in the NE, partly because the seismic line crosses channels from the base of a seamount offset to the south of the main Schlanger Ridge that helps to form the subbasin (see map in Figure 2).

The light green unit thickness is more uniform over the rest of the basin, but

610 the thickest sediments have shifted even further SW than those of the blue unit. The pink Plio-Pleistocene unit is continuously deposited to the SW but is severely cut by channels in the NE half of Seismic Line 1. We could not confidently trace it into the NE subbasin.

There is a deposit of material with high acoustic reflectivity found on both

615 flanks of Schlanger Ridge that may the remnants of an early channel system or perhaps volcaniclastics and shallow carbonates associated with LIR formation. Volcaniclastics are found in the basal sediments of Sites 165, 315, and 316 around the LIR (DSDP Leg 17 Scientists, 1973; DSDP Leg 33 Scientists, 1976) and shallow water carbonates are found in the basal sediments of Site 315.

620 Buried channels are marked by highly reflective seismic packets that are the response from sides of channels or meanders within the channel system (Figure 8). They are prominent in the NE cutting into the boundary between the brown and blue horizons. To the northeast of the Palmyra Basin depocenter we find evidence of a persistent channel formed low in the sediment sequence. We have outlined a

625 channel, shown by dotted lines in the brown sequence, with additional channel 
levees being found in the lower blue sequence. A similar channel cuts into the upper sediment column, suggesting that the position of this large channel is partly controlled by basement topography. Despite these channel systems, there has been a net filling of Palmyra Basin.

630 There may be net loss of the shallowest sediments within Palmyra Basin in the modern system, indicated by downcutting channels. Near Schlanger Ridge there is major downcutting into the older sediment sequences. In the central part of the seismic profile, however, there is both downcutting and filling suggesting that loss of sediment from the upper Palmyra Basin has been episodic and is largely balanced

635 by fresh sediment production upslope.

\section{DISCUSSION AND CONCLUSIONS}

Large-scale regions of elevated topography like the LIR are important for carbonate deposition within the Pacific Ocean. During the late Mesozoic and early Cenozoic, the Pacific CCD was often shallower than the average depth of the mid-

640 ocean ridge system, and carbonate was only deposited on anomalously shallow topography like the LIR or large igneous provinces like the Ontong Java Plateau, Manihiki Plateau, or Shatsky Rise (Neal et al, 1997). The lack of a large deep sediment carbonate reservoir in the equatorial Pacific probably helped to amplify swings in the CCD in the Paleogene (Pälike et al, 2012).

evidence that the high topography has been responsible for collecting a sediment pile that is much thicker than the average in the surrounding tropical Pacific, especially for the Paleogene. The LIR and the sediment aprons around it extend 
carbonate deposition about $5^{\circ}$ to the west of where the intersection of the CCD and

650 average mid-ocean ridge depth should have ended carbonate burial. The LIR and its flank deposits make up roughly $5 \%$ of the total depositional area of equatorial Pacific carbonate zone. Since the sediment pile is mostly carbonates, the preservation of this sediment is important to the Cenozoic carbon cycle. The presence of large areas of mid-depth carbonates ( 2000-3000 m) on topographic

655 highs like the LIR helps to buffer changes in carbonate chemistry of Pacific waters during large atmospheric $\mathrm{CO}_{2}$ transients like the fossil fuel transient today, or perhaps the transient associated with emplacement of the Columbia River Basalts at the early-middle Miocene boundary.

\subsection{LIR sedimentation versus the Maldives Ridge}

660 LIR carbonate sedimentation is different from sedimentation at other pelagic tropical ridges like the Maldives or Hawaii, because the relatively small volume of volcanism built the LIR framework in contrast to voluminous volcanism at the Maldives Ridge or massive individual volcanic centers as in the Hawaiian Island chain. .

665 The LIR has a distinct pattern of volcanism that is later buried beneath sediments. There were large numbers of small seamounts and basalt ridges that formed the LIR, perhaps by crossing small hotspot trails (Pockalny et al, 2015) or by mantle upwarping (Davis et al, 2002). This volcanism formed a relatively wide region of elevated ocean floor with sub parallel seamount ridges, culminating in the 670 Palmyra Basin in the north. 
What is pertinent to the sedimentation is that no large near-sea level basalt platform was formed. Instead, a series of small islands formed that have since sunk to become atolls. Because the ocean crust is about 50 million years older than the seamount volcanism, subsidence from crustal cooling was relatively minor after

675 volcanism stopped. Shallow carbonate production was limited by seamount area that reached into the near-surface ocean. Around the Palmyra Basin, only Kingman Reef and Palmyra Island maintain reefs along the southwestern Kingman Ridge. The seismic evidence suggests that the northeastern Schlanger Ridge may have been only briefly emergent. In between the two bounding ridges, the Palmyra Basin was

$680 \sim 2 \mathrm{~km}$ below the Cretaceous ocean surface. Only 3 other atolls besides Kingman Reef and Palmyra Island (Teraina, Tabuaeran, and Kiritimati) form islands along the LIR. Each of these occupies the summit of a volcanic edifice, separated by $100 \mathrm{~km}$ or more from each other. The lack of large numbers of atolls is evidence that most of the LIR was never above sea level.

685 Further south, the matrix of seamounts that form the LIR has formed many small basins along the ridge. While a few seamounts have joined to form linear chains, many are separated by $50 \mathrm{~km}$ or so, and form subbasins along the ridge. Several subbasins that were crossed during the MGL1208 survey also show development of major channel systems draining sediment from the shallower 690 regions.

In contrast, The Maldives Ridge-a hotspot ridge in the tropical Indian Ocean-exemplifies sedimentation along a ridge with voluminous volcanism. Since the Maldives Ridge was at or near the Paleocene ridge crest when formed at the 
Reunion hot spot (57 Ma, Duncan and Hargraves, 1990) it was also subject to much

695 larger subsidence as well (Coffin, 1993) to provide accommodation for a thick shallow carbonate sequence. The Maldives Ridge consists of a massive volcanic edifice that reached sea level and then slowly subsided (Aubert, 1994; Aubert and Droxler, 1996, Betzler et al, 2015). The central region was further downfaulted and subsided more rapidly than the two flanks of the ridge (Aubert, 1994), The high

700 volume of volcanism produced a very large edifice on which sediment then accumulated. The shallow but downfaulted central part of the ridge provided a shallow sediment catchment as well.

The Maldives platform is as wide as the entire Palmyra basin on the northern LIR (Figure 2) but mostly is less than $500 \mathrm{~m}$ deep. Apparently much of the edifice

705 reached sea level and subsequently subsided more slowly than reefs grew, allowing reef and shallow carbonate sediments to deposit nearly as rapidly as the ridge subsided. The more rapid subsidence of the center forms a deeper Maldives Inner Sea flanked by a series of atolls along each ridge flank (Aubert, 1994). The basalt crust of the Maldives Ridge is now topped by $2-3 \mathrm{~km}$ of shallow-water carbonates

710 (Aubert and Droxler, 1996). The differing volume of volcanism that formed each ridge along with differing subsidence history caused the differences in sedimentation between the Maldives and the LIR. While the Maldives formed a large shallow platform that allowed both reef formation and a catchment for shallow carbonates, volcanism at the LIR formed small isolated islands. Nevertheless the LIR

715 uplift formed mid-depth topography above the Pacific CCD where carbonates could accumulate and then be channeled to its apron. Thus the Maldives became a large 
shallow-water carbonate platform, while the LIR became primarily a reservoir for pelagic carbonates.

\subsection{Sediment deposition in the Palmyra Basin}

In the absence of drilling in Palmyra Basin, we can only infer the ages of different sediment units based upon drilling on the LIR apron. However, it is clear from Site 315 that highest deposition rates regionally occurred in the late Oligoceneearly Miocene, associated not only with the time when Palmyra Basin was crossing the equator but also with the high sedimentation rates and deep CCDs found

725 throughout the Pacific at that time (Lyle, 2003; Moore et al, 2004; Pälike et al, 2012).

The accumulation of sediment within Palmyra Basin is somewhat faster than sediment burial in the LIR apron, but not hugely so. We estimate that there is $1.3 \mathrm{~km}$ of sediment within Palmyra basin, as compared to 800-1000 m drilled on either side of the LIR at Sites 315 and 316 (DSDP Leg 33 Scientific Party, 1973). While the

730 oldest sediments from the DSDP sites contain shallow water carbonates, most of the sediment pile appears to be pelagic in origin. The higher sediment accumulation in Palmyra Basin probably results from the interaction of currents with the ridges surrounding it to preferentially deposit sediment from the tops of the basalt ridge into Palmyra basin. $25 \%$ of the total basin area, shedding of sediment from the ridges alone could not provide all of the excess sediment regionally. Instead, early development of shallow topography by volcanism along the LIR may have initially provided a relatively shallow sea floor, upon which carbonates could be deposited with minimal 
740 dissolution. The large region of turbidite deposition on the flanks of the LIR indicates that a significant fraction of sediment first was deposited on the LIR and then flowed outward from the high topography.

One of the remaining mysteries of LIR sedimentation is how the LIR appears to have generated more pelagic carbonate production regionally than one would

745 normally expect in the pelagic realm. From studies of Pleistocene cores taken on the MGL1208 cruise, the average sediment deposition in Palmyra Basin is close to the level that could be supplied by surface water production. The Pleistocene sedimentation rates (1-2 cm/ky; Lynch-Stieglitz et al., 2015) are similar to the longterm average needed to fill the basin. The amount of shallow bare ridge tops should

750 be sufficient to supply some sediment to the surrounding apron, but it is unclear how the LIR could support voluminous turbidite deposition in the region around it. If there were an 'island effect' of elevated primary productivity along the LIR near islands (e.g., Andrade et al., 2013) it was probably not large. The few islands along the LIR are small and probably have small influence on the regional productivity.

755 Developing a sedimentary balance depends upon better estimates of sediment loss to the LIR apron.

Sediments from Kingman Ridge on the SW side of Palmyra Basin probably are an important sediment source for Palmyra Basin even though there is also significant loss from Kingman Ridge outward to the LIR apron. Because of the 760 prevailing abyssal currents traveling from the SW to the NE, the southern Kingman Ridge should be the most important source of horizontally transported sediment to Palmyra Basin. Sediment waves indicate that the SW to NE current directions 
prevailed over the late Neogene at least. Current activity has shaped the Palmyra basin sediment fill since the basin was first formed. Early in the basin's history,

765 there were high acoustic impedance (high current velocity?) deposits along Schlanger Ridge flanks. Nevertheless, sediment deposition appears to have been biased toward Schlanger Ridge during the Cretaceous and Paleogene (the brown unit in Figure 8), perhaps being sourced by the more massive ridge on the NE of Palmyra basin. Flow of sediments downhill and relatively high current velocity has caused pelagic sediment drape to be poorly developed over Palmyra Basin, as indicated by the mediocre continuity of seismic horizons. Instead of relatively quiet pelagic sediment rain to the sea floor, there is abundant evidence of current sorting that deposited different size classes of sediment in different locations, and there has

775 probably also always been at least some level of downslope transport.

The relatively large amount of channeling in the younger sediments, especially near Schlanger Ridge, may reflect a slowdown in sedimentation since the Miocene, perhaps because of plate tectonic movement away from the equatorial high productivity zone. At Site 315 the highest sedimentation rates broadly 780 matched when Site 315 (now at $4^{\circ} 10^{\prime}$ N, Figure 4) was in the equatorial zone. However, sedimentation rates at Site 315 radically increased after $27 \mathrm{Ma}$, when Site 315 was positioned at $4^{\circ} \mathrm{S}$ rather than near the equator. Clearly other factors were in play to increase the sedimentation since the middle Oligocene. It appears that a major factor in the change in sedimentation was the increase of equatorial Pacific 
785 carbonate deposition in the middle-late Oligocene and broadly deeper CCD (van Andel et al, 1975; Pälike et al, 2012).

\subsection{The LIR and regional carbonate sedimentation}

. DSDP drilling around the LIR has shown that there are thick carbonate sediment deposits around the LIR, with turbidites apparently sourced from the LIR.

790 However, the general elevation of the crust surrounding the LIR must also have contributed to the regional preservation of carbonates. Turbidites are common in the drilled sediments, but a significant but unquantified amount of the sediment column is pelagic in origin. Spot coring (a core every $100 \mathrm{~m}$ or so in the upper sediments) during drilling of these early DSDP sites makes it difficult to assess the

795 Neogene contribution of the LIR to the surrounding apron. However, since carbonate deposition has continued since the Cretaceous, initial uplift during the late Cretaceous, 40 to 50 million years after the local ocean crust originally formed, and initial volcaniclastic sedimentation was sufficient to build a sediment column shallow enough to maintain carbonate burial (DSDP Leg 17 Party, 1973; DSDP Leg

80033 Scientific Party, 1976). Now Sites 315 and 316 are still above the CCD despite being on roughly 120 Ma ocean crust because they both have accumulated nearly 1 $\mathrm{km}$ of sediment. In contrast, the deeper and more distal Site 165 stopped accumulating turbidites in the early Miocene, as it dropped below the CCD.

Today, the ubiquitous presence of channels from the LIR to the apron gives 805 evidence that the LIR itself is still contributing large volumes of sediment to the surrounding region. In Palmyra Basin we find that these channels are both large and active. Moderate levels of anomalous volcanism long after the ocean crust was 
formed combined with relatively unstable sediments accumulating along seamounts at the the LIR have provided both large-scale loss of surface sediments (Lynch-

810 Stieglitz et al, 2015) but also have built significant accumulations of carbonate sediments at and around the LIR.

\section{ACKNOWLEDGEMENTS}

NSF grants OCE-1157486 (M.L.), OCE-1158994 (R.P.), OCE-1159053 (J.L.-S.), and OCE-1158886 (P.J.P.) funded the MGL1208 cruise responsible for collecting the

815 cores, multibeam and seismic reflection data. The captain and crew of the R/V Marcus Langseth and the LDEO Marine Office are gratefully acknowledged for the success of MGL1208. Funding for the analysis and publication of this paper came from USGS Grant G13AC00351 to Pockalny in support of the US Extended Continental Shelf project.

820 Abyssal current data were extracted from the HYCOM reanalysis. Funding to develop HYCOM is from the National Ocean Partnership Program and the Office of Naval Research. Data assimilative products using HYCOM are funded by the U.S. Navy. Computer time was made available by the DoD High Performance Computing Modernization Program. The output is publicly available at http://hycom.org.

\section{FIGURE CAPTIONS}

Figure 1: Location of Line Islands Ridge with respect to the Hawaiian Islands. White dashed lines mark Pacific crustal ages in millions of years. Crustal ages are from Müller et al, 2008. The lack of offsets at fracture zones represents errors 
in the global data set. Red line and stars follow the tectonic backtrack of Palmyra Basin, on the northern Line Islands Ridge based on the fixed hotspot Pacific Plate model of Engebretson et al, 1985, spliced to Gripp and Gordon plate motions for 0-5 Ma. The location of Figure 2 is shown by the box and is the location of MGL1208 survey area E.

835 Figure 2: Bathymetric map of the Northern Line Island Ridge showing satellite bathymetry and multibeam mapping from MGL1208 and from Gardner and Caulder (2010) The map also identifies Palmyra basin, Kingman Ridge, Schlanger Ridge, and Langseth Ridge. Seismic lines 1 and 2 from the MGL1208 E area seismic survey are dashed, while the remainder of the MGL1208 840 trackline is shown as a fine solid line. The box outlines the bathymetry shown in Figure 4.

Figure 3: Regional sediment thickness around the LIR from Divins (2003) and Whittaker et al (2013). The black line outlines the 3000 m bathymetric contour on the LIR. DSDP Site 165 is to the NW of LIR; Site 315 is to the east; and Site

845316 is to the south. Drilled sediment thicknesses are shown. The crest of the LIR is identified to be without sediment in this regional map, reflecting the lack of data.

Figure 4: Bathymetry to the southeast of Seismic line 1, with the seismic reflection profile displayed below. See Figure 2 for the orientation of the figure. The tracklines for seismic lines 1 and 2 are also shown as black lines, and include the trackline as the seismic gear was recovered after Seismic line 2 was completed. The white line shows the ship's track after the seismic experiment. 
Open circles mark the hourly position of the seismic source, while the black circles mark the position at 12-hour intervals marked GMT month/day in 2012. 855 Red arrows mark the start and end of Seismic lines 1 and 2. The Seismic Line 2 profile is in Figure 5. A well-developed perched channel system is imaged in the northeast, next to Schlanger Ridge, where a seamount to the south of the main ridge forms a subbasin. A wide shallow channel system runs downslope from the Palmyra Basin depocenter. The location of sand waves and the seismic $860 \quad$ profiles shown in figure 7 are shown on the right side of Seismic line 1.

Figure 5: Seismic Line 2 from the MGL1208 Site E Survey, crossing the gap between Kingman and Langseth Ridges (west end) and the foot of Langseth Ridge. See Figure 2 and Figure 4 for the line position. Basal sediments tend to drape over topography, although they accumulated faster between basement ridges.

$865 \quad$ Younger channels now erode into the older basin fill.

Figure 6: (A) Bathymetric expression of sediment waves near the gap between Kingman and Langseth Ridges, and (B) maximum abyssal current vectors over LIR from the HYCOM model (Hybrid Coordinate Ocean Model; http://hycom.org), a data assimilating ocean circulation model with $9 \mathrm{~km}$ grid spacing. The $3000 \mathrm{~m}$ contour is highlighted to outline the Northern LIR. Black dots are locations of cores taken on MGL1208. Current vectors through the Kingman/Langseth Ridge gap are $0.2 \mathrm{~m} / \mathrm{s}$, flowing to the $N E$ through the region where sediment waves were found.

Figure 7: Seismic expression of sediment waves near the gap between Kingman and 875 Langseth Ridges from Seismic Line 1. Top, digital subbottom profiler record at 
the same length scale as the bottom MCS record but with higher vertical exaggeration. The profile locations are shown on Figure 4. A prominent horizon may mark a hiatus period, while lower down in the sediment column sediment waves have eroded into older sediment.

880 Figure 8: Seismic interpretation of sediment deposition within Palmyra Basin by interpreting horizons based upong the sediment column drilled at Site 315. Brown marks a sediment packet that is likely Cretaceous-Paleogene in age, blue is probably Oligocene-middle Miocene, and light green is probably late Miocene. Pink sediments are interpreted to be Pliocene-Pleistocene. There are 885 about 1.3 to $1.4 \mathrm{~km}$ of sediment at the depocenter along Seismic Line 1 based on seismic velocities at Site 315. Figure 9: Continuity of seismic horizons in Palmyra Basin (seismic line 1, top profile) compared to Cocos Ridge MV1014 Seismic Line 2 (bottom profile, Liao and Lyle, 2014; profile location is shown in Figure 10). Cocos Ridge forms the northern boundary of the Panama Basin in the eastern Pacific. The basement age along MV1014-Line 2 is $~ 11.5$ Ma, as compared to $\sim 80$ Ma along LIR Seismic Line 1. Both seismic lines are plotted at the same scale, and both used the same GI seismic source. Seismic horizons are much less continuous at LIR than at Cocos Ridge, evidence of higher current activity at the LIR.

895 Figure 10: Maximum current velocities from HYCOM above the Cocos Ridge. Magenta Line marks the position of MV1014 Seismic Line 2 from Liao and Lyle (2014) shown in Figure 9. Black dot is the location of ODP Site 1241 (ODP Leg 202 Scientific Party, 2003) Maximum current velocities range from 0.05 to 0.15 
$\mathrm{m} / \mathrm{s}$, or about $0.1 \mathrm{~m} / \mathrm{s}$ slower than current velocities across the upper Palmyra

$900 \quad$ Basin along LIR Seismic Line 1.

\section{REFERENCES}

Adam, C. and A. Bonneville, 2005, Extent of the South Pacific Superswell. Journal of Geophysical Research, B110, B09408,14pp, doi:10.1029/2004JB003465.

905

Arthur, M. A., W. E. Dean, and S. O. Schlanger (1985), Variations in the global carbon cycle during the Cretaceous related to climate, volcanism, and changes in atmospheric $\mathrm{CO}_{2}$, in AGU Geophysical Monograph 32, pp 504-529, American Geophysical Union.

910

Aubert, O., 1994. Origin and stratigraphic evolutio of the Maldives (central Indian Ocean, Rice University, Houston Texas.

Aubert, O., Droxler, A.W., 1996. Seismic stratigraphy and depositional signatures of 915 the Maldive carbonate system (Indian Ocean). Marine and Petroleum Geology 13 (5), 503-536.

Barth, Ginger A, Eakins, Barry W., Scheirer, Daniel S, Wong Florence L., and Jones, Meghan R.,2013; A fresh look at the geologic evolution of Kingman Reef and Palmyra Atoll, U.S. Line Islands. American Geophysical Union, Fall Meeting 2013, abstract \#OS13B-1698,

Berger, W.H., Adelseck, C.G.J., and Mayer, L.A., 1976, Distribution of carbonate in surface sediments of the Pacific Ocean: Journal of Geophysical Research, 81, 2617-2627.

Betzler, C., Kroon, D., Reijmer, J.J.G., 2000. Synchroneity of major late Neogene sea level fluctuations and paleoceanographically controlled changes as recorded by two carbonate platforms. Paleoceanography 15 (6), 722-730.

Clark, J.D., Kenyon, N.H., Pickering, K.T., 1992. Quantitative analysis of the geometry of submarine channels: implications for the classification of submarine fans. Geology 20, 633-636. 
935 Coffin, M. F. (1993). Emplacement and subsidence of Indian Ocean plateaus and submarine ridges. Synthesis of results from scientific drilling in the Indian Ocean, AGU Geophys. Monograph 70, 115-125.

Davis, A.S., L.B. Gray, D.A. Clague, J.R. Hein, 2002. The Line Islands revisited: New ${ }^{40} \mathrm{Ar} /{ }^{39} \mathrm{Ar}$ geochronologic evidence for episodes of volcanism due to lithospheric extension. Geochemistry Geophysics Geosystems, 3, 28 pp. , doi: $10.1029 / 2001 G C 000190$

Divins, D.L., Total Sediment Thickness of the World's Oceans \& Marginal Seas, NOAA $945 \quad$ National Geophysical Data Center, Boulder, CO, 2003. www.NGDC.noaa.gov/mgg/sedthick/sedthick.html

DSDP Leg 17 Shipboard Scientific Party,1973. Site 165. Init Repts, DSDP, 17, 47-102.

950 DSDP Leg 33 Shipboard Scientific Party, 1976, Site 315. Init Repts, DSDP, 33, 37-104.

DSDP Leg 33 Shipboard Scientific Party, 1976, Site 316. Init Repts, DSDP, 33, 105159.

955 Duncan, R. A., and R. B. Hargraves, 1990. 40Ar/39Ar geochronology of basement rocks from the Mascarene Plateau, the Chagos Bank, and the Maldives Ridge, in Proc IODP, Sci Res., 115, edited, pp. 43-51, IODP, College Station TX.

Engebretson, D.C., Cox, A., Gordon, R.G., 1985. Relative Motions Between Oceanic 960 and Continental Plates in the Pacific Basin. Geological Society of America Special Paper 206, 59 pp

Flood, R.D., 1988. A lee wave model for deep-sea mudwave activity. Deep Sea Research, 35 (6), 973-983.

Gardner, J.V., and B.R. Calder, 2010. U.S. Law of the Sea Cruise to Map the Southern Flank of the Kingman Reef-Palmyra Atoll section of the Line Islands, Equatorial Pacific Ocean, University of New Hampshire, Center for Coastal and Ocean Mapping/Joint Hydrographic Center, Durham, 81 pp.

Goff, J.A., Smith, W.H.F., Marks, K.M., 2004. The contributions of abyssal hill morphology and noise to altimetric gravity fabric. Oceanography 17 (1), 2437.

Gripp, A.E., Gordon, R.G., 1990. Current plate velocities relative to the hotspots incorporating the NUVEL-1 global plate motion model. Geophysical Research Letters 17 (8), 1109-1112. 
Hamilton, E. L., R. T. Bachman, W. H. Berger, T. C. Johnson, and L. A. Mayer (1982), Acoustic and related properties of calcareous deep-sea sediments, Journal of Sedimentary Petrology, 52(3), 733-753.

Hays, J.D., Saito, T., Opdyke, N.D., Burckle, L.H., 1969. Pliocene-Pleistocene sediments of the equatorial Pacific: Their paleomagnetic, biostratigraphic, and climatic record. Geological Society of America Bulletin 80 (August), 1481-1514.

985

Jackson, E.D., and S.O. Schlanger, 1976. Regional syntheses, Line Islands Chain, Tuamotu Island Chain, and Manihiki Plateau, central Pacific Ocean. Init Repts, DSDP, 33, 915-927. .

990 Johnson, G.C., Toole, J.M., 1993. flow of deep and bottom waters in the Pacific at $10^{\circ}$ N. Deep Sea Research I, 40(2), 371-394.

Jones, M.R., Eakins, B., and Barth, G., 2013, Seafloor geology of the U.S. Line Islands Region (abs.): American Geophysical Union, 2013 Fall Meeting, OS13B-1699.

995

1000

Larson, R.L., 1991, Latest pulse of Earth: Evidence for a mid-Cretaceous superplume. Geology, 19, 547-550.

Liao, Y., Lyle, M., 2014. Late Miocene to Pleistocene sedimentation and sediment transport on the Cocos Ridge, eastern tropical Pacific Ocean. Marine Geology $355,1-14$.

Lyle, M., Wilson, P.A., 2006. Leg 199 synthesis: evolution of the equatorial Pacific in the early Cenozoic. In: Wilson, P.A., Lyle, M., Firth, J.V. (Eds.), Proceedings of the ODP, Scientific Results, 199. Ocean Drilling Program, College Station TX, pp. 1-39.

Lynch-Stieglitz, J., et al. (2015), Glacial-interglacial changes in central tropical Pacific surface seawater property gradients, Paleoceanography, 30, 423-438,

1010 doi:10.1002/2014PA002746.

Marcantonio, F., Lyle, M., Ibrahim, R., 2014. Particle sorting during sediment redistribution processes and the effect on ${ }^{230} \mathrm{Th}$-normalized mass accumulation rates. Geophysical Research Letters 41, 5547-5554.

Mayer, L.A., Shipley, T.H., Winterer, E.L., 1986. Equatorial Pacific seismic reflectors as indicators of global oceanographic events. Science 233, 761-764. 
Miller, M.C., Komar, P.D., 1977. The development of sediment threshold curves for unusual environments (Mars) and for inadequately studied materials (foram sands). Sedimentology 24, 709-721.

Mitchell, N., Lyle, M., 2005. Patchy deposits of Cenozoic pelagic sediments in the central Pacific. Geology 33, 49-52.

1025

Morgan, W.J., 1972. Deep mantle convection plumes and plate motions. American Association of Petroleum Geologists Bulletin, 56, 203-213.

1030 Müller, R.D., Sdrolias, M., Gaina, C. Roest, W.R., 2008. Age, spreading rates, and spreading asymmetry of the world's ocean crust. Geochemistry, Geophysics, Geosystems 9 (4), 19 pp.

Neal, C. R., Mahoney, J. J., Kroenke, L. W., Duncan, R. A., \& Petterson, M. G. (1997). The Ontong Java Plateau. Large Igneous Provinces: Continental, Oceanic, and Planetary Flood Volcanism, 183-216.

Normark, W.R., Spiess, F.N., 1976. Erosion on the Line Islands archipelagic apron: effect of small-scale topographic relief. Geological Society of America Bulletin 87, 286-296.

ODP Leg 202 Scientific party, 2003. Site 1241, Proceedings of the Ocean Drilling Program, Initial Reports, doi:10.2973/odp.proc.ir.202.112.2003

1045 Orwig, T.L., 1981. Channeled turbidites in the eastern central Pacific Basin. Marine Geology 39, 33-57.

Pälike, H., Lyle, M., Nishi, H., Raffi, I., Ridgwell, A., Gamage, K., Klaus, A., and the Exp 320/321 Shipboard scientific party, 2012. A Cenozoic record of the equatorial Pacific carbonate compensation depth. Nature 488, 609-614.

Paskevich, V.F., Wong, F.L., O'Malley, J.J., Stevenson, A.J., and Gutmacher, C.E., 2011, GLORIA sidescan-sonar imagery for parts of the U.S. Exclusive Economic Zone and adjacent areas: U.S. Geological Survey Open-File Report 2010-1332, http://pubs.usgs.gov/of/2010/1332/

Pockalny, R., Scheirer, D., Barth, G., Eakins, B., 2015. A two-phase volcanic model for the origin of Line Islands Ridge. AGU Fall meeting. 
Raff, A.D., 1973. Underway Data. Initial Reports, Deep Sea Drilling Project 17, 337 364.

Rosburg, K. C., K. A. Donohue, E. Chassignet, 2012. Performance Evaluation of HYCOM Gulf of Mexico. Ocean Sciences Meeting, Salt Lake City, Utah

1065

Schlanger, S.O., Winterer, E.L, 1976. Underway geophysical data: navigation, bathymetry, magnetics, and seismic profiles. . Init Repts, DSDP, 33, 655-693.

Schlanger, S.O., Garcia, M.O., Keating, B.H., Naughton, J.J., Sager, W.W., Haggerty, J.A., Philpotts, J.A., 1984. Geology and geochronology of the Line Islands. Journal of Geophysical Research, Earth 89 (B13), 11,261-11,272.

Smith, W.H.F., Sandwell, D.T., 1997. Global seafloor topography from satellite altimetry and ship depth soundings. Science 277, 1957-1962.

Stow, D.A.V., Hernandez-Molina, F.J., Llave, E., Sayago-Gil, M., Diaz del Rio, V., Branson, A., 2009. Bedform-velocity matrix: the estimation of bottom current velocity from bedform observations. Geology 37 (4), 327-330.

1080 Talley, L.D. 2007. Hydrographic Atlas of the World Ocean Circulation Experiment (WOCE): Volume 2: Pacific Ocean. International WOCE Project Office, Southampton, UK. www-pord.ucsd.edu/whp_atlas/Pacific_index.html

Torsvik, T.H., Müller, R.D., Van Der Voo, R., Steinberger, B., Gaina, C., 2008. Global 1085 plate motion frames: toward a unified model. Reviews of Geophysics 46, 44 pp.

van Andel, T.H., Heath, G.R., Moore, T.C., 1975. Cenozoic History and Paleoceanography of the central equatorial Pacific Ocean, GSA Memoir 143. Geological Society of America.

Whittaker, Joanne, Alexey Goncharov, Simon Williams, R. Dietmar Müller, German Leitchenkov (2013) Global sediment thickness dataset updated for the Australian-Antarctic Southern Ocean, Geochemistry, Geophysics, Geosystems. DOI: 10.1002/ggge.20181 

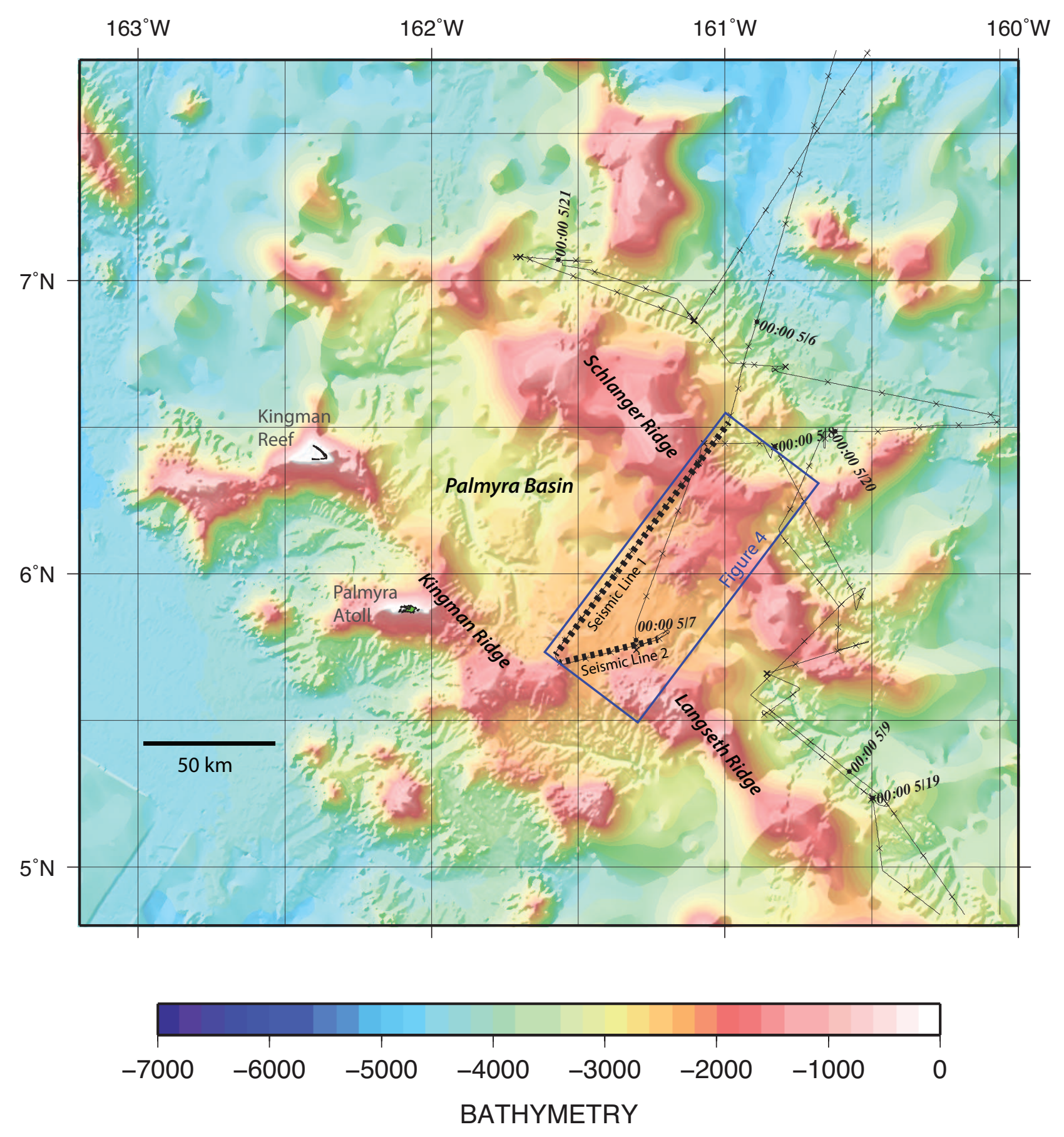

Lyle et al, Figure 2

Figure 2: Northern LIR map

(n)

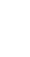




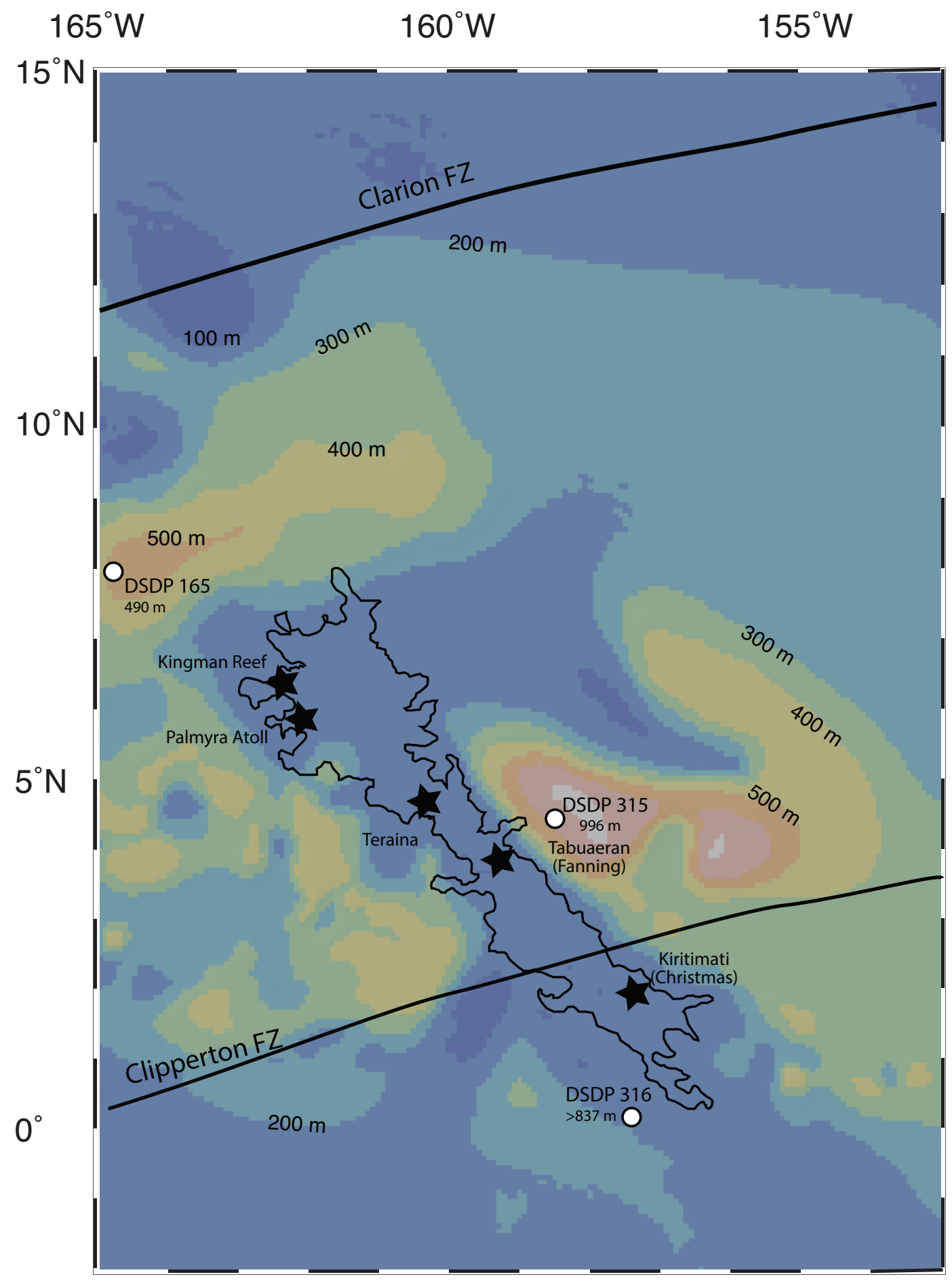

Lyle et al, Figure 3 
Lyle et al, Figure 4

Figure 4: Palmyra Basin multibeam plus seismic

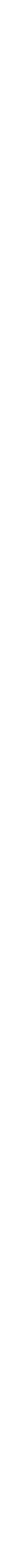

end Line 2
Langseth giry $(\mathrm{m})$ 0

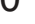

\section{Figure 4: Palmyra Basin multibeam plus seismic}

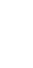

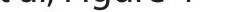




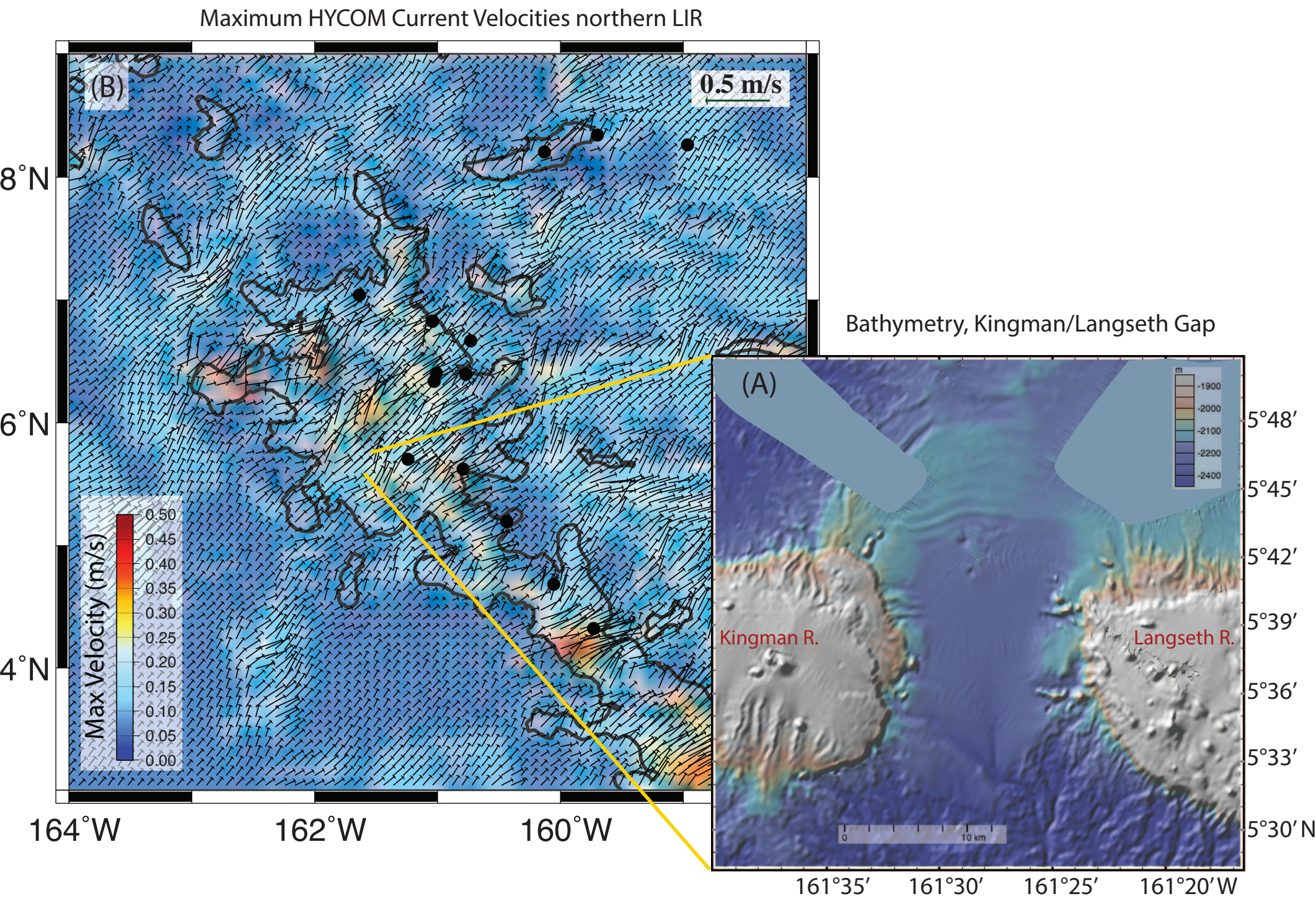

Lyle et al, Figure 6 
Figure 8: Interpretation of seismic line 1

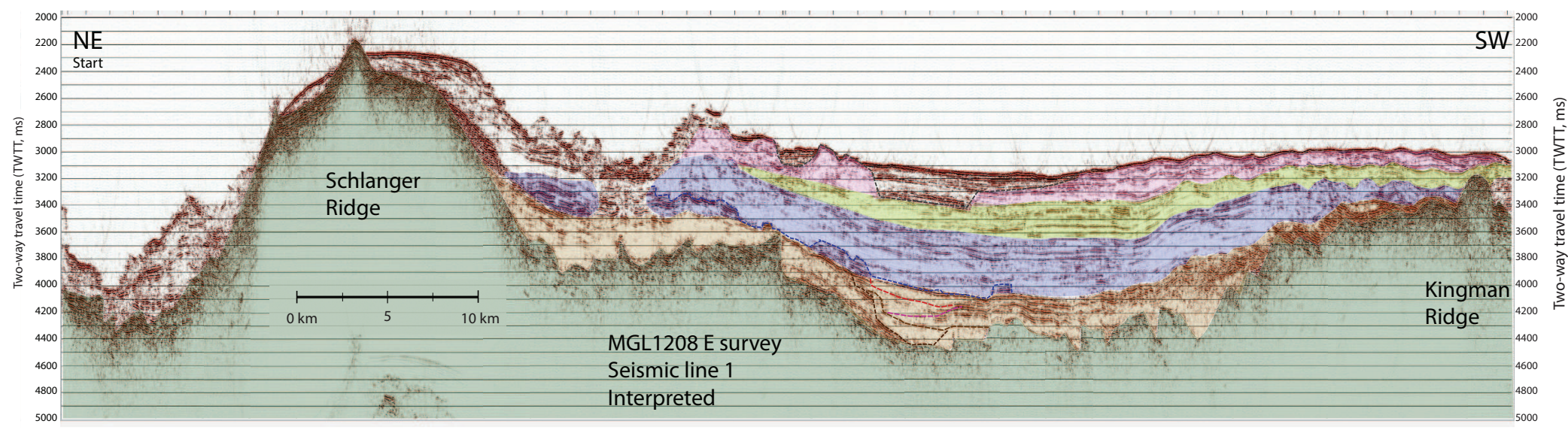

Lyle et al, Figure 8

\author{
Figure 8: Interpretation of seismic line 1
}

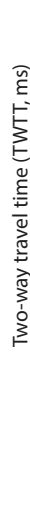

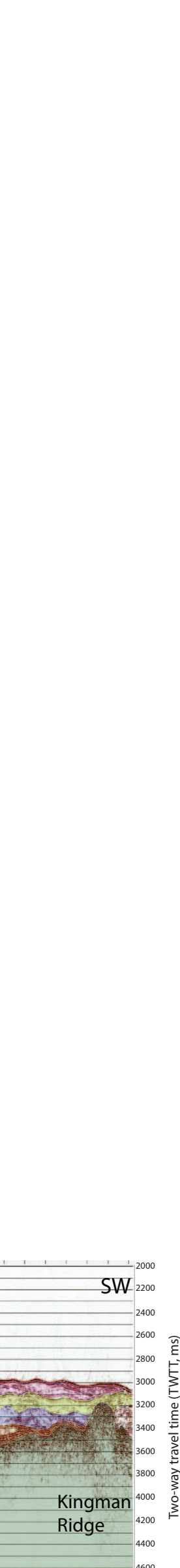


Lyle et al, Figure 9

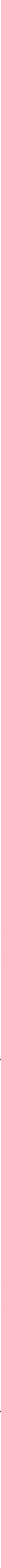

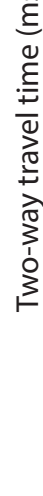

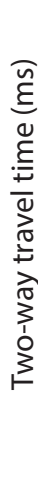

Figure 9: comparison of LIR and Cocos $R$ seismic profiles 


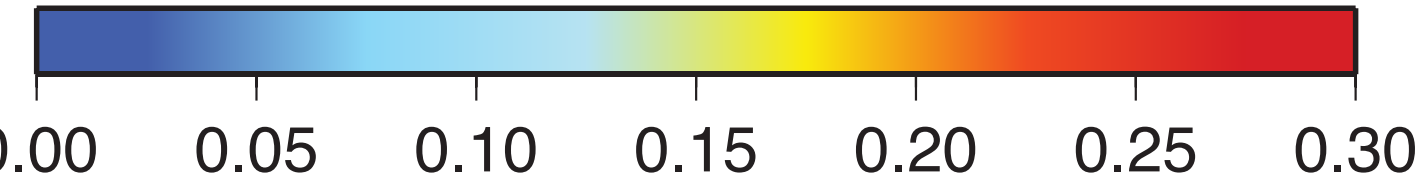 \\ HYCOM Max. Velocity (m/s)}

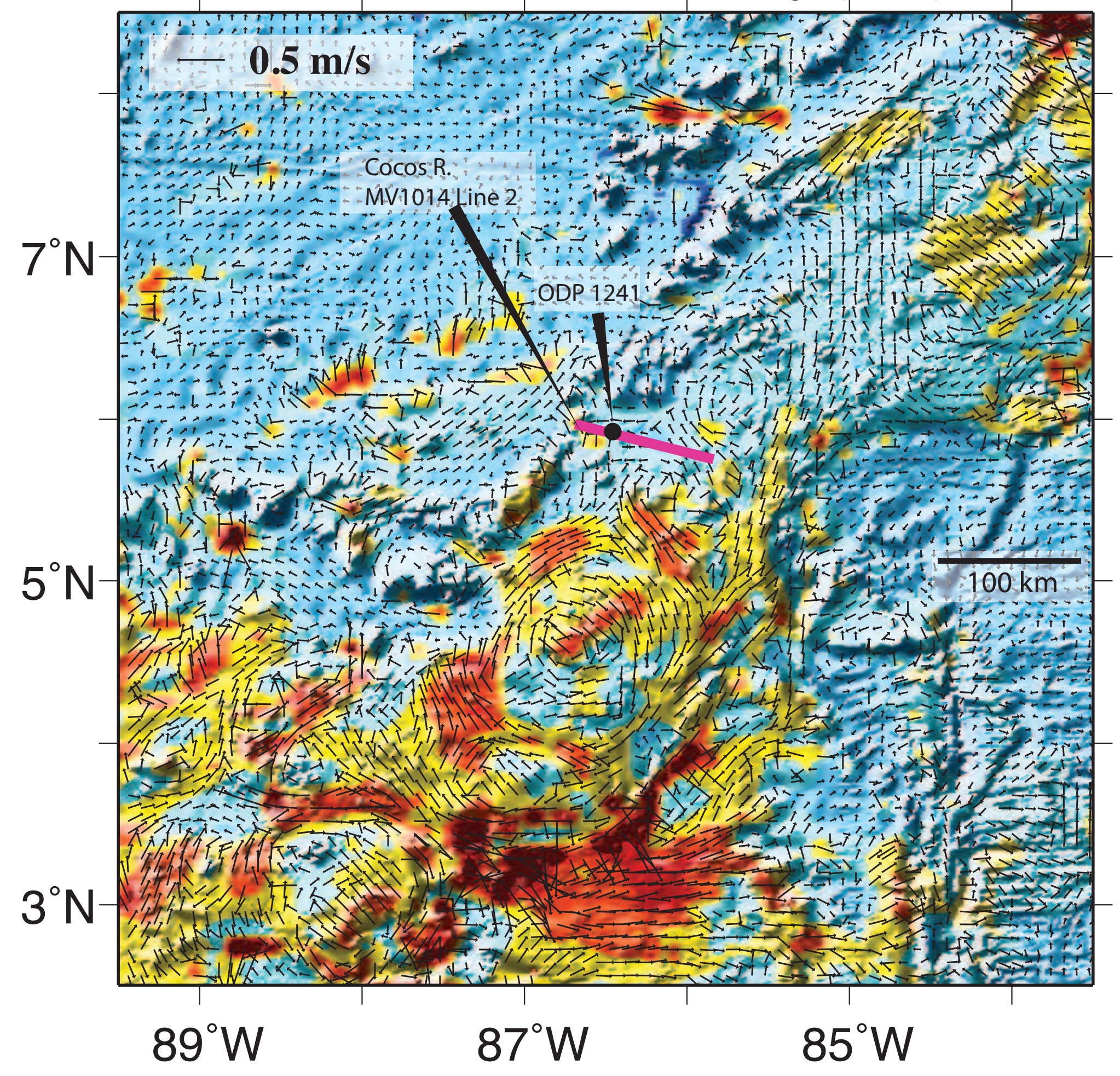

$5^{\circ} \mathrm{N}$

$87^{\circ} \mathrm{W}$

$85^{\circ} \mathrm{W}$ 